\title{
PELAKSANAAN PRODUKSI PRODUK HALAL FOOD MENGGUNAKAN AKAD KERJASAMA DI TINJAU DARI PRINSIP TABADUL AL-MANAFI DAN AN'TARADHIN
}

\author{
Neni Hardiati ${ }^{1}$, Atang Abdul Hakim ${ }^{2}$ \\ ${ }^{1}$ Program Studi Magister Hukum Ekonomi Syariah, UIN Sunan Gunung Djati Bandung \\ ${ }^{2}$ UIN Sunan Gunung Djati Bandung \\ Email: nenihardiati@gmail.com
}

\begin{abstract}
Abstrak
Akad kerjasama dalam prinsip Tabadul al-manafi dan An'taradhin sangat efektif diterapkan pada produksi halal food. Sebab hal tersebut terlihat dari dasar-dasar hukum yang ada di dalamnya. Prinsip tersebut yaitu aqidah, syari'ah dan akhlak. Sistem ekonomi ini berdasarkan nilai-nilai Islam, yaitu pemerataan, kegunaan, keseimbangan, kemaslahatan dan keuniversalan (rahmat li al-aalmin), sehingga aktivitas produksi masa depan mengalami peningkatan kesejahteraan ekonomi di atas landasan prinsip syariah. Menurut hemat penulis bahwa akad kerjasama memiliki manfaat untuk di aplikasikan kepada pelaku produksi produk halal food. Sumber hukum yang menjadi induk dalam kegiatan ekonomi, dan dasar-dasar filosofis hukum Islam lainnya yang sebagai pokok dalam memajukan ekonomi Islam dimuka bumi, dan harus sesuai dengan koridor syariah. Kemaslahatan harus di capai dalam kegiatan ekonomi Islam dengan menjauhi segala larangan-larangan yang tidak sesuai dengan prinsip syariah. Dalam tulisan ini menggunakan metode penelitian kualitatif deskriptif dengan pendekatan yuridis normatif menggunakan studi kepustakaan. Sehingga dengan metode tersebut dapat digali nilai-nilai filosifis dalam pengembangan ekonomi Islam dalam bidang produksi produk halal.
\end{abstract}

Kata Kunci: Produksi Halal, Kerjasama, Tabadul Al-Manafi, An'taradhin.

\begin{abstract}
Cooperation agreement in the principles of Tabadul al-manafi and An'taradhin is very effectively applied. For this is evident from the fundamentals of the law. This principle is aqidah, shari'ah and morals. This economic system is based on Islamic values, namely equality, usefulness, balance, kindness and universality (rahmat li al-aalmin), so that the people of Indonesia in the future experience improved economic welfare on the basis of sharia principles. According to thrifty authors that the cooperation agreement has the benefit to be applied to the actors of the production of halal food products. The source of the law that underlies all economic activities, and other philosophical foundations of Islamic law that form the basis in developing the Islamic economy anywhere and in any form, and should not be out of the sharia corridor. Benefit is the main objective in Islamic economic activities and avoids all forms of normality. Through this paper by qualitative research method, with normative juridical approach through literature study. So that with this method can be excavated filosifis values in the development of Islamic economy in the field of halal product production.
\end{abstract}

Keywords: Halal Production, Cooperation, Tabadul Al-Manafi, An'taradhin. 


\section{A. PENDAHULUAN}

Islam ialah agama yang mencangkup dari segala aspek kehidupan, tiga dasar ajarannya, yaitu aqidah, syari'ah dan akhlak. Kolerasi ketiganya dalam tatanan Islam yang terhubung sedemikian rupa sehingga menjadi bentuk tatanan yang saling keterkaitan. Syariah Islam di bagi menjadi dua yaitu aspek ibadah dan mu'amalah (Simal, 2019). Kemudian menurut Mardani dalam (Sari \& Budi, 2017) menyatakan bahwa dalam masalah muamalah syariat Islam lebih dominan kepada pola-pola, asas-asas, landasan-landasan yang universal ketimbang memikirkan jenis maupun bentuk secara khusus. Sekiranya kegiatan muamalah dilaksanakan dan di eksistensikan dengan tujuannya yang di harapkan oleh hukum syara, agar memuat asas dan keyakinan yang dikukuhkan oleh syara' tersebut dan harapan agar kemaslahatan masyarakat muslim melampaui kemudaratan dari dirinya, sehingga jenis muamalah bisa diterima. Jika landasan tersebut terwujud dan terpatri di setiap pelaku bisnis, hal ini akan menjadikan pelaku usaha tersebut memiliki sikap jujur, amanah, dan sesuai syariah Islam. Salah satu hal yang bisa mewujudkan rasa keadilan dan rasa percaya dalam sebuah kegiatan bisnis kerjasama yaitu dilandasi rasa tolong menolong, karena suatu usaha ada individu yang memiliki modal namun tidak bisa menjalankan usaha. Sebab itu ada pula seseorang yang bisa menjalankan usaha dan bekerjasama dalam modal usaha dan keduanya memiliki tujuan dan bisnis yang serupa.

Usaha menurut Islam yang di dalamnya ada campur tangan orang lain harus diperhatikan keterlibatannya dan tidak mencari keuntungan hanya untuk diri sendiri agar kegiatan tolong menolong dan saling manfaaat diperoleh, jika ada yang bekerja pada kita, kita sebagai pelaku usaha wajib membayarkan upah kepada pegawai sesuai hasil kerja dan kesepakatan yang sudah disepakati, dalam berkerja sama membangun usaha produksi pun harus ada kesepakatan yang jelas sehingga manfaat akan dirasakan. Aktivitas kerja sama dalam Islam sering dikenal dengan syirkah. Syirkah yaitu kegiatan usaha individu dengan minimal dua orang dalam perserikatan membangun suatu usaha melalui modal yang jelas disepakati di awal sebagai perjanjian dan usaha tersebut akan dikembangkan bersama-sama yang mana keuntungan dan kerugiannya juga disepakati bersama (Saripudin, 2018). Melaui syirkah akan mendapatkan kebermanfaatan sebagai jalan dalam permodalan seperti syirkah inan tidak harus memiliki modal yang sama dalam mendirikan usaha baik itu produksi maupun usaha lainnya, sehingga saling menguntungkan. Para ahli ekonomi Islam mendukung adanya peran syirkah atau kerja sama dalam menumbuhkan perekonomian umat (Setiawan, 2013). 
Bagi hasil melalui syirkah memiliki dua sistem yaitu bagi untung (profit sharing) dan bagi hasil (revenue sharing). Profit sharing ialah bagi hasil yang dihitung dari penghasilan setelah dikurangi biaya pengelolaan dana, sementara revenue sharing yaitu bagi hasil yang dihitung melalui total penghasilan pengelolaan modal. Melalui aktivitas kerja sama ini kedua belah pihak mengikatkan diri untuk memiliki hak dan hukum yang serupa terhadap usaha yang didirikan oleh keduanya (Hidayatullah, 2020). Relasi antara manusia satu dan lainnya menjadi sebuah keharusan dalam mejaga usahanya. Kegiatan ekonomi Islam memiliki asasasas acuan kepada Al-Qur'an dan Hadist. Asas-asas universal dalam kegiatan ekonomi bersifat tetap ialah ajaran tauhid, manfaat, keadilan, kebebasan, kewajiban, persahabatan, dan lainnya. Di dalam kegiatan muamalah ada prinsip tabadul al-manafi atau prinsip pertukaran manfaat dan prinsip an'taradhin atau saling ridho yang akan mendatangkan kemaslahatan (Sulistiani, 2018). Secara praktek ekonomi Islam selalu tumbuh dengan keadaan zaman dan kebudayaan. Namun bagi umat muslim membuat produk makanan halal adalah salah satu hal penting karena makanan termasuk kebutuhan utama sehari-hari yang di butuhkan manusia. Seiring dengan itu, costumer muslim mengharapkan hasil produksi terjamin kehalalannya dan kesehatannya. Sehingga aspek halal, haram, thayyib dan subhat mengandung nilai spriritual dalam menggambarkan kemuliaan etika dan ahlak individu. Sebab itu Syariah Islam sangat menilai daya tarik yang tinggi dalam menetapkan produk konsumsi halal, haram, dan subhat menurut Ali dalam (Nurdin et al., 2019). Industri halal belakangan ini menjadi sebuah gaya hidup bahkan bukan dari segi halal food, seperti halal tourism, halal fashion, maupun kegiatan usaha halal lainnya. Sebab itu fenomena tersebut perlu dikaji untuk memastikan kebenarannya agar saling memberikan manfaat dan saling ridho antara pelaku usaha maupun konsumen dalam sebuah produksi sebagai awal menjamin kehalalan produk terutama pada makanan atau halal food.

Tujuan penelitian ini untuk mengetahui pelaksanaan produksi produk halal food menggunakan akad kerjasama dan di tinjau dari prinsip tabadul al-manafi atau asas manfaat dan prinsip an'taradhin yakni saling rihdo dalam bekerjasama dalam suatu usaha untuk mewudukan keadilan kedua belah pihak yang di dasari oleh prinsip tersebut.

\section{B. METODE}

Penulisan artikel jurnal ini menggunakan metode penelitian kualitatif, dengan pendekatan yuridis normatif melalui studi kepustakaan. Studi kepustakaan adalah cara yang dipakai untuk menghimpun data-data atau sumber-sumber yang berhubungan dengan topik yang diangkat dalam suatu penelitian. Studi literatur bisa didapat dari berbagai sumber seperti 
jurnal, buku dokumentasi, internet dan pustaka, dan lain-lain. Dalam penulisan artikel ini, studi literatur yang dilakukan oleh penulis yaitu dengan melakukan pencarian terhadap berbagai sumber tertulis, baik berupa buku-buku, arsip, majalah, artikel, dan jurnal, atau dokumen-dokumen yang relevan dengan permasalahan yang dikaji. Kegiatan penunjang yang dilakukan dalam melakukan kajian literature ini meliputi mencari, membaca, dan menelaah pendapat - pendapat dari para ahli dan bahan pustaka yang memuat teori-teori yang relevan. Sehingga dengan metode tersebut dapat digali nilai-nilai filosifis dalam pengembangan ekonomi Islam dalam bidang produksi produk halal (Sugiyono, 2015). Metodologi yang digunakan yakni metodolog studi Islam, melalui proses ilmiah, tepat dan tuntas dalam memaknai ajaran Islam secara menyeluruh dari berbagai aspek sumber, pemahaman ajarannya pada sumber sejarahnya (Atang Abd Hakim \& Mubarok, 2017).

\section{HASIL DAN PEMBAHASAN}

\section{Produksi Dalam Islam}

Manusia adalah mahluk sosial yang memerlukan orang lain dalam hidupnya seperti halnya kegiatan muamalah. Keperluan sendiri dapat ditentukan melaui konsep mashlahah yang pada pokokya harus teruji kehalalannya. Syaitibi merangkum kesejahteraan manusia dalam hidup terdiri dari hal-hal yang bersifat dharuriyyah, hajiyyah, dan tahsiniyyah. Dharuruiyyah (penjagaan terhadap agama, jiwa, akal, keturunan). Dalam Islam hal ini jadi penting bagi pelaku industri ketika memproduksi barang/jasa yang dibutuhkan oleh konsumen (Rochmanto \& Widiyanto, 2014).

Manusia memiliki suatu keutuhan dari dua pokok dasar yang tidak dapat dipisahkan yaitu jasmani dan rohani. Manusia agar bisa bertahan dalam hidup harus adanya makanan, minuman, pakaian dan perlindungan. Sebab itu manusia diharuskan agar berproduksi dan bekerja agar terpenuhi kebutuhan hidup (Fauzia, 2018).

Secara umum produksi ialah menjadikan sumber- sumber baku untuk menghasilakan barang jadi, atau suatu kegiatan perjalanan sehingga barang input diolah menjadi output. Produksi ialah membuat karya kekayaan dengan menggunakan sumber alam oleh manusia. Sedangkan dalam ekonomi Islam produksi ialah bentuk kegiatan yang dilaksankan untuk menumbuhkan kegunaan ataupun memanfaatkan sumber daya alam yang sudah Allah SWT sediakan kemudian di olah oleh manusia untuk menjadi sesuatu yang berguna sehingga menghasilkan sebuah kemaslahatan dalam memenuhi kebutuhan hidup di dunia. Namun dalam Islam menghasilkan produk halal sebuah keharusan karena sesuai prinisp syariah Islam (Turmudi, 2017). Sedangkan menurut para ekonomi muslim dalam (Imroatus Sholiha, 2018) 
diantaranya menurut:

a. Ibnu Kaldun (1332-1406 M), mendefinsikan produksi ialah membuat produk benda maupun jasa untuk mencukupi kebutuhan hidup untuk dimanfaatkan secara perorangan atau kelompok.

b. Al-Ghazali (1058-1111M), produksi yaitu sebuah ibadah yang penting dalam hidup. Khusunya proses mengolah bahan baku sebagai fadru al-kifayah dalam kegiatan sosial. Memproduksi untuk memenuhi kebutuhan masyarakat luas, sehingga jika tidak mencukupi kebutuhan dalam produksi semua akan diminta pertanggungjawaban di akhirat. Kegiatan ekonomi Islam harus tepat guna sebab merupakan tugas spiritual individu.

c. Imam Asy-Syaitibi, mengemukankan bahwa produksi adalah menaikan nilai manfaat suatu benda untuk kesejahteraan, sehingga terwujud merawat 'maqashid syariah' yang memiliki 5 unsur dasar yaitu agama, jiwa, akal, keturunan, dan harta benda.

d. Rahman (1995), menekankan keadilan dalam sebuah produksi adalah suatu keharusan guna kebermanfaatan bersama.

Sedangkan halal menurut Islam artinya halal atau dibolehkan, halal dalam makanan adalah makanan yang tidak di ragukan lagi untuk di konsumsi. Menurut Marzuki Hall Ballentine dalam (Mathew et al., 2014), sebagai umat muslim harus mematuhi halal dalam mengonsumsi makanan dan menjauhkan dari yang di larang atau haram, halal ini dapat dilihat dari seluruh kegiatan dari mulai produksi sampai siap konsumsi. Makanan haram jika sumbernya juga haram hal ini akan membahayakan jiwa raga dan pikiran individu seseorang. Di Indonesia sendiri yang penulis tahu halalnya sebuah produk adanya sertfikat halal yang di akui dan dikeluarkan oleh MUI, dengan adanya sertifikat tersebut, produk makanan menjadi suatu yang penting untuk menjauhkan salah konsumsi dalam hal ini produk yang dilarang.

\section{Akad Kerjasama}

Berbisnis tidak terlepas dari campur tangan orang lain ialah metode untuk menemukan rezeki dari sang Khalik melaui bermuamalah, dalam hal ini Allah SWT sudah mensyariatkan ketentuan hukum yang bukan hanya kepada hal-hal ibadah saja namun perkara muamalah. Dalam sebuah kerjasama adanya setidaknya minimal 2 orang dalam melakukan perjanjian atau akad. Adapun akad kerjasama dalam ekonomi Islam yang sering di gunakan yaitu akad syirkah.

Menurut Fatwa Dewan Syariah Nasional-Majelis Ulama Indonesia Nomor: 114/DSNMUI/IX/2017, Syirkah ialah perjanjian kerja sama antara dua pihak atau lebih untuk sebuah 
bisnis tertentu dimana semua pihak memberikan kontribusi dana/modal usaha (ras al-mal) yang mempunyai aturan yaitu keberhasilan dan kerugian dibagi sesuai nisbah yang disepakati atau secara proposional. Syirkah ini termasuk wujud syirkah amwal atau lebih dikenal dengan syirkah inan (MUI, 2017). Secara bahasa Syirkah ialah gabungan harta individu satu dengan yang lainnya sehingga tidak bisa dibedakan. Menurut Muhammad al-Syarbini alKhatib, mendefinisikan syirkah ialah ketetapan hak bagi dua individu atau lebih melalui jalan yang masyhur atau diketahui. Menurut istilah Syirkah, para fuqaha memiliki pendapat masing-masing, menurut Setiawan dalam Rangkuman Abdurrahman al-Jaziri meringkas opini-opini tersebut diantaranya yaitu menurut Sayyid Sabiq, syirkah adalah akad yang dilakukan minimal dua orang yang berserikat pada dasar harta (modal) dan hasil. Muhammad al-Syarbini al-Khatib, menurutnya syirkah merupakan menetapkan hal pada oarang bersyirkah dengan sama dan diketahui. Menurut Syihab al-Din al-Qalyubi wa Umaira mendefiniskan syirkah dalam (D. Setiawan, 2013) yakni penetapan hak pada dua orang atau lebih. Dengan demikian bisa di simpulkan syirkah ini yakni aktivitas kerjasama membangun usaha lewat proses penggabunagn harta serta dalam mendirikan usahanya juga silih berkontribusi, dengan modalnya boleh berbeda tetapi keuntungan dan kerugiannya disesuaikan dengan tiap-tiap pemodal sesuai kesepakatan.

Menurut Majid dalam (D. Setiawan, 2013), dasar hukum syirkah ialah mubah atau boleh. Hal tersebut diperlihatkan oleh dibolehkannya praktek syirkah oleh baginda Rasulullah dilaksanakan umat Islam pada masa itu, Al-Quran dan hadits yang menjelasakan mengenai syirkah di antaranya: "Sesungguhnya kebanyakan dari orang-orang bersyirkah itu, sebagian mereka berbuat zalim terhadap sebagian yang lain, kecuali orang beriman dan mengerjakan amal salih (Q.S. Shad 38:24).

Hadist Abu Dawud dari Abu Hurairah, Rasulullah Saw bersabda: "Sesungguhnya Allah SWT telah berfirman, "Aku jadi yang ketiga antara dua orang yang berserikat selama yang satu tidak khianat kepada yang lainnya, apabila yang satu berkhianat kepada pihak yang lain, maka keluarlah aku darinya." (HR. Abu Dawud).

Adapun rukun syirkah menurut para ulama meliputi:

a. Sighat (Ijab dan Qobul), hendaknya dalam dalam kalimat terucap jelas sesuatu yang di transaksikan dan juga mengandung izin membelanjakan benda dari perseronya, Rasyid (Saripudin, 2018).

b. Al' Aqidain (subjek perikatan), anggotanya yang berserikat harus baligh, merdeka dan tidak ada paksaan.

c. Mahallul Aqd (objek perikatan), berupa modal dengan tunai maupun kerjanya, 
Sedangkan syarat syirkah meliputi:

a. Dua individu atau lebih dalam beryirkah harus memiliki kecakapan seperti sudah baligh, berakal sehat, dan kehendak sendiri.

b. Menggabungkan hartanya sampai tidak bisa dibedakan dengan yang lainnya.

c. Untung dan rugi disepakati bersama

Menurut (Anggadini, 2017) Syirkah dibagi dua jenis yaitu syirkah milik (syirkah alamlak) dan syirkah transaksi (syirkah al-uqud). Syirkah Amlak (milik) yaitu kegiatan perserikatan dalam suatu barang yang untuk dimiliki bersama. Syirkah ini dibagi dua ialah syirkah ikhtiariyyah, yaitu kerjasama dalam memiliki suatu benda dengan dasar suka sama suka, kemudian syirkah ijbariyyah, yaitu gabungan harta secara tepaksa, misalnya harta warisan dari ahli waris yang baru meninggal sehingga harta tersebut menjadi milik bersama bagi ahli warisnya. Sementara syirkah uqud (akad) ialah perserikatan yang terjadi karena adanya akad transaksi antara pihak yang bermitra untuk mendapatkan keuntungan dan manfaat bersama. Syirkah ini pun dibagi ke beberapa syirkah diantaranya, syirkah inan, abdan, mudharabah,wujuh dan muwafadah. Namun dalam penelitian ini penulis mencoba memasukan Syirkah Inan yaitu kerjasama dua orang atau lebih dalam membangun usaha yang memiliki tujuan mendapatkan keuntungan, modal dalam syirkah inan tidak harus sama. Contohnya: Ani dan ana ingin membangun usaha produk halal food yaitu kuliner khas Bandung, Ani memiliki uang 60 juta, sedangkan ana memiliki modal 40 juta karena dibutuhkan 100 juta untuk membangun usahanya, dengan kesepakatan keuntungan 50\%: 50\% namun jika mengalami kerugian disesuaikan dengan modal awal yaitu Ani 60\% dan Ana 40\%. Dalam syirkah ini disyartakan modal harus berupa tunai (uang), sedangkan barang tidak bisa dijadikan modal kecuali ketika adanya perjanjian dihitung nilainya. Sehingga dalam akad kerjsama tersebut memiliki nilai-nilai tabadul al-manafi sebab saling memberikan keuntungan dan manfaat bersama baik dari segi usaha yang di bangun maupun dalam kerjasama dalam produksinya dan terdapat nilai-nilai an'taradhin karena dalam sebuah kerjasama tersebut di dasari atas dasar saling ridho yang tidak mengandung unsur-unsur paksaan dan atas kesepakatan bersama baik ketika memulai akad kerjasama maupun dalam menjalankan usahanya.

\section{Kajian Prinsip Tabadul Al-manafi dan An'Taradhin dalam Fislafat Hukum Ekonomi Islam (Muamalah)}

Anshori (2018) menyatakan bahwa filsafat ekonomi ialah pokok dari sebuah tatanan ekonomi yang didirikan. Berdasarkan filsafat ekonomi akan dicapai tujuan-tujuan yang akan 
di capai, seperti tujuan ekonomi dalam produksi,konsumsi,distribusi,pengembangan ekonomi, kebijakan fiskal, dan lainnya. Filsafat ekonomi Islam ditekankan pada prinsip triangle, yaitu filsafat Tuhan,manusia dan alam. Dasar filsafat ekonomi Islam terletak manusia dengan Tuhan, alam dan manusia lainnya.Dimensi filsafat ekonomi Islam inilah yang membedakan dengan ekonomi lainnya seperti ekonomi kapitalis dan sosialisme. Filsafat ekonomi yang Islami, mempunyai paradigma yang selaras dengan nilai logis, etis, dan estestis yang Islami untuk digunakan ke dalam budi pekerti manusia. Dari filsafat ekonomi ini di wahyukan juga nilai-nilai instrumental sebagai alat aturan permainan (rule of game) suatu kegiatan. Sehingga point yang menjadi pokok berbedanay antara sistem ekonomi Islam dan sistem ekonomi lainnya terdapat pada falsafahnya yang memiliki nilai-nilai dan tujuan. Dalam ekonomi Islam terdapat nilai-nilai dari Al-Qur'an dan Hadist berupa asas-asas yang universal. Sementara ekonomi lain fokus terhadap hukum dan sebab akibat kegiatan ekonominya, Islam lebih mengedepankan dalam pembahasan nilai-nilai budi pekerti yang ada di dalam gerakan ekonomi tersebut.

Menurut L. Hakim (2012) bahwa pokok syariah ialah untuk menjurusakan kegiatan ekonomi, agar selaras dengan prinsip-prinsip syariah. Sementara akhlak membimbing dalam kegiatan ekonomi manusianya agar selalu mengedepankan nilai moralitas dan etika dalam mencapai tujuan. Akhlak yang terpancar dari iman akan mewujudkan integritas yang membuat good corporate governance dan market disiplin baik. Filsafat hukum fiqh muamalah atau falsafah al-tasyri' fi al-mu'amalah istilah sesuatu yang berkaitan dengan hukum Islam yang terdiri dari tujuan hukum (maqashid). Prinsip hukum (mabadi atau mahiyat), prinsip hukum atau usus al-hukm, kaidah hukum, wasthatiyyat wal harakiyah fi alhukm. sementara Hasbi Ash Shiddieqy menambahkan ciri khas, serta watak, tabiat yang merupakan dasar pembentukan dan pembinaan hukum Islam.

Tujuan di syariatkannya dasar-dasar hukum dalam bidang ini yaitu dalam rangka menjaga kepentingan orang-orang mukallaf terhadap harta mereka sehingga tidak dirugikanoleh tindakan-tindakan orang lain, sehingga bisa dimanfaatkan harta miliknya itu dalam memenuhi kepentingan hidupnya. bahkan lebih jauh mereka bisa mengembangkan dengan baik tanpa dihadapkan dengan hal-hal negatif yang bisa menekan dinamika pengembangan harta tersebut, dengan sikap negatif kelompok lainnya.

Menurut (Atang Abdul Hakim, 1997), tujuan hukum memiliki arti al- masalahat ialah mengembangkan sistem ekonomi dengan acuan nilai-nilai Islam, diantaranya keadilan, kemanfaatan, keseimbangan dan keuniversalan atau rahamt li al-alamin, sebab itu masayarakat Indonesia masa depan mengalami peningkatan kesejahtraan ekonomi dalam 
dasar prinsip syariah. pemerataan kesejahtraan tidak berarti tingkat kesejahtraan masyarkat harus merata, tetapi kesejahtraan yang memiliki nilai keadilan, kesejahtraan yang sesuai porsinya, ialah kesejahtraan material dan immaterial. Tujuan ini diupayakan pencapaiannya oleh produsen yang memiliki pedoman terhadap prinsip syariah sesuai teori dan manfaat yang dikembangkan oleh Jeremy Betham, beliau mengatakan bahwa manfaat umum adalah asas dalam mencaapi tujuan bersama.

Prinsip-prinsip hukum ekonomi Islam antara lain adalah sebagai berikut:

a. Prinsip Aqidah atau prinsip Tauhid

Shomad (2017) menyatkan bahwa, prinsip ini ialah pondasi dalam hukum Islam yang menekankan bahwa:

1). Harta benda yang kita miliki hanya amanah dari Allah sebagai pemilik hakiki. Dalam mendapatkan dan mengelolanya harus baik (al-thayyibat) dalam rangka dan mencari kemaslahatan karunia Allah (ibtighamin fadhilah).

2). Manusia bisa berhubungan langsung dengan Allah. Ekonomi Islam ialah ekonomi yang berdasarkan ketuhanan. Sistem ini bertitik tolak dari Allah, bertujuan akhir kepada Allah, dan menggunakan sarana yang lepas dari syariat Allah.

b. Prinsip Keadilan

Amin (2014) menyatakan, prinsip ini menyangkut segala aspek kehidupan, ialah prinsip paling penting, karena Allah SWT telah memerintahkan adil antar manusia satu dengan yang lainnya, sesuai firmannya: "Sesungguhnya Allah menyuruh (kamu) berlaku adil dan berbuat kebajikan, memberi kepada kaum kerabat, dan Allah melarang perbuatan keji, kemungkaran, permusuhan. Dia memberi pengajaran kepadamu agar kamu mengambil pelajaran" (Q.S An-Nahl:90).

c. Prinsip Al-Ihsan (berbuat kebajiakn), memberikan manfaat kepada orang lain lebih dari kebutuhannya.

d. Prinsip Al-Mas'uliyah (accountability), prinsip pertanggungjawaban dari berbagai aspek, yaitu: pe srrtanggung jawaban anatar manusia satu dan lainnya (mas'uliyah alafrad), pertanggungjawaban dalam masyarakat (mas'uliyah al mujtama). Manusia dalam masyarakat diwajibkan melaksanakan kewajibannya dalam mencapai kesejahtraan anggota masyarkat secara komprehenship serta tanggung jawab pemerintah (mas'uliyah tanggung jawab ini berkaitan dengan baitul mal.

e. Prinsip keseimbangan yaitu prinsip ak-wasthiyah (al'itidal, moderat, keseimbangan). Syariat Islam mengetahui hak-hak privasi dengan batas-batas tertentu.

f. Prinsip kejujuran dan kebenaran, merupakan pokok ahlakul kharimah. 
g. Prinsip transaksi yang meragukan dilarang, akad transaksi harus tegas, jelas, dan pasti. Baik benda yang menjadi objek akad, maupun harga barang yang di akadkan tersebut.

h. Prinsip transaksi yang merugikan dilarang, setiap transaksi yang merugikan diri sendiri maupun pihak kedua dan pihak ketiga dilarang. sebagaimana sabda Rasulullah saw: "Tidak boleh membahayakan (merugikan) diri sendiri dan tidak boleh membahayakan (merugikan) pihak lain.

i. Prinsip kepentingan umum. Prinsip ini menekankan keutamaan kepentingan umum yang harus di dahulukan tanpa menyebabkan kerugian individu. Sebagaimana kaidah fiqhiyah: "bila bertentangan antara kemaslahtan sosial dan kemaslahatan individu, maka diutamakan kebermanfaatkan umum.

j. Prinsip manfaat. Objek transaksi harus mempunyai kegunaan, transaksi terhadap objek yang tidak bermanfaat menurut syariat dilarang.

k. Prinsip transaksi yang mengandung riba dilarang

1. Prinsip suka sama suka (saling rela atau an'taradhin). prinsip ini juga berdasarkan hadist Rasulullah saw: "tidak lain jual beli harus melalui jalan suka sama suka". (Hr. Ibnu Majah).

m. Prinsip tidak ada paksaan. Setiap orang memiliki kehendak yang bebas dalam menetapkan akad, tanpa tunduk kepada paksaan transaksi apapun, kecuali hal yang diharuskan oleh norma keadilan dan kemaslahatan umat.

Beranjak pada di atas dapat ditarik kesimpulan, bahwa hakkatnya kerjasama produksi produk halal di harapkan memperhatikan unsur suka sama suka atau an'taradhin karena prinsip ini sangat diutamakan dalam sebuah kerjasama agar tidak ada hal yang merugikan kedua belah pihak,kemudian memperhatikan kebermanfaatan bersama, karena tujuan dari produksi dalam kebermanfaatan satu sama lain.

Asas-asas hukum ekonomi Islam adalah sebegai berikut:

a. Tabadul Al-Manafi (pertukaran manfaat), kerjasama (musyarakah) dan kepemilikan

Asas pertukaran manfaat (tabadul al-manafi) direduksikan dari Q.S Al-Imran: 191. Dalam ayat ini menjelaskan bahwa sesuatu yang diciptakan oleh Allah Swt mempunyai nilai kemaslahatn dan kegunaan bagi manusia. Firman Allah adalah aturan dan norma hukum yang bertujuan terciptanya kemaslahatan (al-mashalih) manusia, dunia dan akhirat. Norma hukum tersebut oleh para ulama diinterpretasi sehingga melahirkan, salah satunya, norma fiqh muamalah. Norma fiqh muamalah sebagai bagian norma hukum Islam memiliki tujuan yang sama, yaitu al-mashalih. Al- 
mashalih dapat diartikan manfaat atau kebaikan (Sjaichul Hadi Permono, 2010). (Atang Abdul Hakim, 1997) menyatakan bahwa mendistribusikan secara merata kepada seluruh umat, dan seluruh elemen masyarakat, bukan sebuah monopoli demi kepentingan perorangan atau kelompok. Pertukaran manfaat mengandung pengertian keterlibatan orang banyak, baik secara seseorang maupun kelembagaan. Sebab itu, dalam pertukaran kegunaan dalam norma kerjasama (almusyarakat). Sedangkan, pertukaran manfaat terkait dengan hak milik (haq al-milk) individu, sebab perputaran kegunaan hanya bisa terdapat dalam benda yang dimiliki, meskipun sebenarnya hak milik mutlak hanya ada pada Allah Swt, sementara manusia hanya mempunyai hak kegunaan. Proses pertukaran manfaat melalui norma al-musyarakat dan norma haqalmilk berakhir di norma al-ta'awun (tolong-menolong). Menurut (Atang Abdul Hakim, 2011) dalam Islam al-ta'awun hanya terjadi dalam kebaikan dan ketaqwaan (al-khairat atau al-birr wa al-taqwa) serta dalam hal yang membawa manfaat bagi semua.

b. An'Taradhin asas pemerataan kesempatan, an'tardhin (suka sama suka atau kerelaan) dan adam al-gharar (tidak penipuan atau spekulasi)

Kholid (2018) menyatakan bahwa asas pemerataan ialah kelanjutan, sekaligus salah satu wujud aplikasi asas keadilan dalam kajian hukum Islam. Pada tataran ekonomi, prinsip ini menempatkan manusia sebagai makhluk yang memiliki kesempatan yang sama untuk memiliki, mengelola dan menikmati sumber daya ekonomi sesuai dengan kemampuannya. Sementara itu, prinsip ini yaitu bentuk praktek ajaran islam mengenai perputaran harta yang tidak boleh hanya berkisar dikalangan orang kaya (al-aghnia), sehingga atas pokok ini hak-hak sosial dirumuskan. Rumusan hak-hak sosial di antaranya yaitu teori perpindahan hak milik, sewa menyewa, gadai, pinjam-meminjam dan utang piutang. Teori perpindahan hak milik diterapkan oleh hukum Islam dengan, contoh: kerjasama dalam produksi yang bisa berupa akad mudharabah dan musyarakah, salam atau ishtina', zakat infaq, shadaqah, hibbah, dan waris, sewa menyewa dengan al-isti'arat gadai dengan al-rahn, dan pinjam meminjam dengan al-qardh. Teori-teori ini adalah sarana untuk menciptakan suasana perekonomian yang bersih sehingga lalu lintas perniagaan dapat dinikmati oleh semua lapisan masyarakat secara merata, tanpa adanya monopoli pihak tertentu.

An'taradhin ialah salah satu asas fiqh mu'amalah. Ia memiliki arti saling merelakan atau suka sama suka. Kerelaan dapat berupa kerelaan melaksanakan suatu 
bentuk muamalah, dan atau kerelaan dalam menerima atau menyerahkan harta yang menjadi obyek perikatan, serta bentuk muamalah lainnya. Ia merupakan salah satu prasyaratan sahnya suatu transaksi bermuamalah di anatara para pihak yang terlibat. Sehingga, ia merupakan kelanjutan dari azas pemerataan, dan bersinergi dengan asas 'adam al-gharar, artinya prilaku 'an taradhin memungkinkan tertutupnya sifat-sifat gharar dalam berbagai bentuk transaksi mu'amalah Hal ini dapat terjadi, karena' adam al-gharar merupakan kelanjutan dari 'an tharadhin. Al-gaharar yaitu sesuatu yang tidak diketahui atau tidak jelas apakah ia ada atau tidak ada. Dalam gaharar ada unsur spekulasi bahkan penipuan yang dapat menghilangkan 'an taradhin. 'adam al-gharar berisi arti bahwa pada setiap bentuk muamalah tidak boleh ada unsur gharar, yaitu tipu daya atau sesuatu yang menyebabkan salah satu pihak merasa dirugikan oleh pihak lain sehingga menyebabkan hilangnya unsure kerelaan dalam melakukan suatu transaksi.

\section{Analisis Teoritis}

Berdasarkan bahasan di atas, berikut pandangan penulis yang berkaitan dengan kerjasama produksi dalam prinsip Tabadul Al-Manafi (saling memberikan manfaat) dan Prinsip an' taradhin (suka sama suka atau kerelaan) cocok diterapkan pada kegiatan kerjasama produksi. Seiring dengan prinsip hukum Islam yang di kemukakan di atas, bahwa pelaksanaan ekonomi dalam kerjasama produksi diharuskan merujuk kepada dasarnya, ialah Al-Qur'an dan hadist. Sebab hal itu berkaitan dengan penjelasan tersebut. Penulis memilih pada asas Tabdul Manfi (saling memberikan manfaat), pemeratan kesempatan, an'taradhin (saling ridho) dan adam al-gharar (tidak ada penipuan atau spekulasi).

Asas pemerataan ialah asas pelengkap dari asas saling memberikan manfaat dalam kerjasama sebuah produksi, prinsip ini sekaligus implementasi prinsip keadilan dalam teori hukum Islam. Para tataran ekonomi,prinsip ini menempatkan manusia sebagai makhluk yang memiliki kesempatan yang sama untuk memiliki, mengelola dan menikmati sumber daya ekonomi sesuai dengan kemampuannya. Fikri et al., (2018) menyatakn disamping asas itu tidak boleh harta hanya berputar dikalangan orang kaya (al-aghnia), sehingga atas dasar ini hak-hak sosial dirumuskan. Rumusan hak-hak sosial di antara yaitu teori perpindahan hak milik, sewa menyewa, gadai, pinjam meminjam dan utang piutang. Teori perpindahan hak milik diterapkan oleh hukum Islam melalui kegiatan transaksi kerjasama dengan menggunakan akad mudharabah dan musyarakah, jika jual beli bisa berupa kaad murabahah, salam atau ishtisna, zakat, sodaqoh, hibah dan waris, sewa menyewa melalui al-isti'arat gadai 
dengan al-rahn, dan pinjam meminjam dengan al-qard. Teori-teori ini ialaah sarana untuk menciptakan suasana perekonomian yang bersih sehingga lalu lintas perniagaan dapat dirasakan oleh semua lapisan masyarakat secara merata, tanpa adanya monopoli pihak lain.

Dengan demikian, hipotesis awal penulis awal bahwa mekanisme kerjasama produksi makanan halal lebih dititik beratkan kepada asas manfaat atau saling menguntungkan disertai saling ridho, hal ini menurut hemat penulis bahwa kerjasama produksi makanan sesuai dengan fatwa kegiatan ekonomi yang dilaksanakan oleh masyarakat pada umumnya dan sesuai dengan Fatwa Dewan Syariah Nasional Majelis Ulama Indonesia Nomor: 114/DSNMUI/IX/2017, tentang akad syirkah yang ditetapkan pada tanggal 28 Djulhijjah 1438 H/19 september 2017 M yang telah mengatur akad kerja sama secara keseluruhanya. Namun demikian, pada prinsipnya produksi produk halal menggunakan akad kerjasama ini diharuskan memperhatika unsur kemanfaatan, saling menguntungkandan unsur suka sama suka. Namun, ternyata berbagai prinsip seperti penjabaran penuilis di atas harus diutamakan. Hal ini dianjurkan kepada kedua belah pihak dalam melakukan transaksi agar tidak terjadi ketidakadilan dan penipuan yang akan menimbulkan tidak ada saling percaya dalam setiap kegiatan kerjasama produksi halal food.

\section{KESIMPULAN}

Pelaksanaan akad kerjasama dalam produksi produk halal food membutuhkan sumber daya alam dan sumber daya manusia lainnya untuk mencapai tujuan keadilan, memiliki manfaat dan keuntungan yang di landasi prinsip tabadul al-manafi dan an' taradhin karena tidak mungkin kedua belah pihak tidak saling suka dalam melangsungkan kegiatan akad kerjasama. Sistem ekonomi ini berdasarkan nilai-nilai Islam, yaitu pemertaan, kegunaan, keseimbangan, dan keuniversalan (rahmat li al-aalmin), melalui adanya asas pertukaran manfaat, dan saling ridho atau suka sama suka. Sebab apapun yang diciptakan oleh Allah SWT di dunia ini memiliki nilai manfaat bagi manusia dan alam, nilai-nilai tabadul al-maanfi dan an'atardhin ini sesuai dengan firman Allah SWT yakni sebagai syariat dan norma hukum yang memiliki tujuan dalam menciptakan maslahat bagi manusia, dunia dan akhirat.

\section{DAFTAR PUSTAKA}

Amin, M. (2014). Konsep Keadilan Dalam Perspektif Filsafat Hukum Islam. Al-Daulah: Jurnal Hukum Dan Perundangan Islam, 4(02), 322-343.

Amwaluna: Jurnal Ekonomi dan Keuangan Syariah Vol. 2 No. 1 January 2018 Page 118-133 
Al-Arif, M. Nur Rianto. Dasar-dasar Ekonomi Islam, Solo: PT Era Adicitra Intermedia, 2011.

Anggadini, S. D. (2017). Analisis Implementasi Syirkah Pada Koperasi. Jurnal Riset Akuntansi, 6(1). https://doi.org/10.34010/jra.v6i1.516

Anshori, A. G. (2018). Filsafat hukum hibah dan wasiat di Indonesia. UGM PRESS.

Asyhadie, Z. (2016). Hukum Bisnis Prinsip dan Pelaksanaannya di Indonesia. Jakarta: Rajawali Pers.

Fauzia, I. K. (2018). Prinsip Dasar Ekonomi Islam Perspektif. Premadama Group.

Fikri, A. L., Yasin, M., \& Jupri, A. (2018). Konsep Pengelolaan Koperasi Pesantren untuk Kesejahteraan Ekonomi Masyarakat: Telaah Surah Al-Hasyr Ayat 7. Jurnal Ilmiah Ekonomi Islam, 4(02), 103.

Gufron, M. I. (2015). Peningkatan Produksi dalam Sistem Ekonomi Islam sebagai Upaya Pemberdayaan Ekonomi Umat. Dinar: Jurnal Ekonomi dan Keuangan Islam, 2(1).

Hakim, A. A., \& Mubarok, J. (2017). Metodologi Studi Islam. Bandung: Rosdakarya.

Hakim, A. A. (1997). Filsafat Hukum Islam. Bandung: Yayasan Piara.

Hakim, A. A. (2011). Fiqih Perbankan Islam. Bandung: Refika Aditama.

Hakim, L. (2012). Prinsip-Prinsip Ekonomi Islam. Jakarta: Erlangga.

Hidayatullah, M. S. (2020). Implementasi Akad Berpola Kerja Sama dalam Produk Keuangan di Bank Syariah (Kajian Mudharabah dan Musyarakah dalam Hukum Ekonomi Syariah). Jurnal Hadratul Madaniyah, 7(1), 34-41.

Juliqah, A. (2015). Implementasi sistem produksi secara Islam pada makanan \& minuman di UMKM Karya Bakti Makanan \& Minuman Rembang (Doctoral dissertation, UIN Walisongo).

Karim, A. A. (2012). Ekonomi Mikro Islami. Jakarta: Raja Grafindo Persada.

Kholid, M. (2018). Prinsip-Prinsip Hukum Ekonomi Syariah Dalam Undang-Undang Perbankan Syariah. Asy-Syari'ah, 20(2), 145-162.

Mannan, M. A. (2016). Teori dan Praktek Ekonomi Islam. Yogyakarta: Dana Bhakti Prima Yasa,

Mathew, V. N., Abdullah, A. M. R. binti A., \& Ismail, S. N. binti M. (2014). Acceptance on Halal Food among Non-Muslim Consumers. Procedia-Social and Behavioral Sciences, 121, 262-271.

MUI, F. D. (2017). Fatwa Dewan Syariah Nasional-Majelis Ulama Indonesia. Journal of Chemical Information and Modeling, 53(9), 6-9.

Nurdin, N., Novia, N., Rahman, A., \& Suhada, R. (2019). Potensi Industri Produk Makanan Halal Di Kota Palu. Jurnal Ilmu Ekonomi Dan Bisnis Islam, 1(1), 1-12.

Qaradhawi, Y. (2014). Halal dan Haram. Bandung: Jabal

Rochmanto, B. A., \& Widiyanto, I. (2014). Pengaruh Pengetahuan Produk Dan Norma Religius Terhadap Sikap Konsumen Dalam Niat Mengkonsumsi Produk Makanan Dan Minuman Halal (Studi Kasus di Kota Semarang). Fakultas Ekonomika dan Bisnis. 
Sari, M. P., \& Budi, I. S. (2017). Keutamaan Prinsip Taradhin Pada Praktik Penjualan (Studi Pada Business Centre Smesa Mart SMKN 1 Banjarmasin. 1-7.

Sari, W. (2014). Produksi, Distribusi, Dan Konsumsi Dalam Islam. ISLAMICONOMIC: Jurnal Ekonomi Islam, 5(2).

Saripudin, U. (2018). Aplikasi Akad Syirkah Dalam Lembaga Keuangan Syariah. Al Amwal, $1(1), 26-40$.

Setiawan, D. (2013). Kerja Sama (Syirkah) Dalam Ekonomi Islam. Jurnal Ekonomi Universitas Riau, 21(03), 8681.

Setiawan, M. H. (2020). Keistimewaan Fiqh Muamalah/Sistem Ekonomi Islam Dengan Sistem Ekonomi Lainya. Al-Mizan: Jurnal Ekonomi Syariah, 3(1), 78-98.

Sholiha, I. (2018). Teori Produksi dalam Islam. Iqtishodiyah: Jurnal Ekonomi dan Bisnis Islam, 4(2).

Shomad, A. (2017). Hukum Islam: Penormaan prinsip syariah dalam hukum indonesia. Jakarta: Kencana.

Simal, A. H. (2019). Pelaksanaan Jual Beli Dengan Menggunakan Akad As-Salam Ditinjau Dari Prinsip Tabadul Al-Manafi. Tahkim, XV(1), 109-124.

Sugiyono. (2015). Metode Penelitian Pendidikan. Bandung: Alfabeta.

Sulistiani, S. L. (2018). Eksistensi Filsafat Hukum Islam dalam Pengembangan Ekonomi Islam Indonesia. Amwaluna, 2, 2-7.

Turmudi, M. (2017). Produksi Dalam Perspektif Ekonomi Islam. Islamadina, 7(1), 45. 